\title{
Quality Assessment in the Service Area of Expertise in an Institution of Public Health Sector
}

\author{
Jose Antonio Hernández Contreras, María Dolores Esquivel Hernández, \\ Ana María González Ponce \\ Universidad del Papaloapan, San Juan Bautista Tuxtepec, México \\ Email: jahernandez@unpa.edu.mx
}

Received 17 November 2014; revised 20 December 2014; accepted 28 December 2014

Copyright (C) 2015 by authors and Scientific Research Publishing Inc.

This work is licensed under the Creative Commons Attribution International License (CC BY). http://creativecommons.org/licenses/by/4.0/

\section{(c) (i) Open Access}

\begin{abstract}
In Mexico over time, economic crisis has worsened the health sector, where those most affected are the lower class, so that people with disease do not have access to private health services, given the high cost that this represents, just as people who are not beneficiaries of the Mexican Institute of Social Security by its Spanish initials IMSS, Institute of Security and Social Services for State Workers by its Spanish initials ISSSTE and other insured agencies providing public health services have no options to solve their health problems.
\end{abstract}

\section{Keywords}

Health Sector, Service Quality, Service

\section{Introduction}

The evaluation of service quality in institutions aimed at providing social security related performance of the individual is one of the most important issues today. It is noteworthy that these institutions are directed to specific sector workers.

[1] people have different wants and needs and therefore different quality standards. It is important to evaluate the quality of service rendered by institutions for social security of the individuals, as such services or facilities are indispensable for anyone.

Currently, the issue of quality in the health service is one of the most important and investigated by organizations, in many cases the quality of service provided by these health institutions are not exactly expected by users, so many organizations seek through study methods (research, surveys, interviews, real testimonials, etc.), create 
proposals for continuous improvement feedback or make a promised service.

The World Health Organization (WHO) sets some variables that should be in health services: a high level of professional excellence, efficient use of resources, minimal risk to the patient, a high degree of patient satisfaction and a final impact on health. The concept of quality has historically referred to different aspects of the activity of any undertaking an organization, at times behaved as a school of thought that permeates the entire institution or has been understood as the quality of a product or service or the quality of a process or style to generate a product or provide a service [2]. Whatever its design has served to generate different progress on all of the service, but has also generated misconceptions about the quality and control, user or buyer and they must produce, businessman or salesman. It is in the early nineties when Department staff quality reduced to very few people because it is thought that the quality of goods and manufactured service is everyone's responsibility, begins to worry about what really matters: the quality of human relationships. Enough attention to the area of administration and services are provided and quality circles and total quality philosophy spread. The most recognized definition is the author Avedis Donabedian School of Public Health, Michigan, who has been the pioneer of this issue in the context of health, their concepts have had great influence in Latin America, "Quality Health Services it is an attribute of medical care that can occur in varying degrees" [3].

The quality of care is to offer a quality service based on patient needs beyond the expected [4].

Patient satisfaction is one of the most important results, not only depends on the quality of offered services but also their expectations [5]. The patient will be satisfied if the services meet and exceed their expectations [6].

For services that consumers actually surprised in a positive way, satisfaction can mean delight. Satisfaction may be associated with feelings of ambivalence when a mixture of positive and negative experiences associated with the service received [7].

Regarding the service in the health sector should be considered as one of the main pillars in terms of speed, accessibility, empathy and efficiency when patients meet the different request. The provision of services in public health centers appear to be inefficient because the resources are operating mostly funded by the federal government and a small portion by users. While the private sector in service delivery is most efficient given the ability to pay people who have come to this, the health sector, as an institution providing service, is increasingly concerned to develop strategies to improve service quality and ensure optimal service delivery. Health systems are in transition due to multiple factors such as technological advances, economic pressures and increased demand from users.

\section{Materials and Methods}

The experimental investigation was not cross; as it was intended to observe the phenomena of study as given in its natural context, without altering any variables and descriptive; because it measured the perceptions of external customers or service users in order to describe what is investigated [8]. A mixed approach to identify the level of satisfaction and to identify aspects of the service with which patients are dissatisfied [9] was used.

An assessment tool adapted to the needs of the institution was used; assessment of satisfaction with health services, patient satisfaction with medical and nursing consultation and citizen evaluation of hospital service, which served to measure the expectations and experiences of users, and which consists of 48 reagents and using ladders Likert-type and open questions. Likewise, the critical incident technique, which consisted of user information about current incidents they see as good or bad aspects of service use; the advantage of the method of critical incidents lies in the use made by users for requirements themselves.

With the information obtained from this research it can help to create a strategy of Institutional quality service that contributes to the continuous improvement of quality and thus customer satisfaction is achieved.

\section{Results and Discussion}

According to the results of the surveys of service users, it can be seen that overall, the majority of users surveyed perceived a good relationship between the patient-doctor-nurse since the results show that users accessed this service mostly once a month, so it is assumed that the frequency of attending influenced when getting the service good interpersonal skills achieved, and both patients and doctors could establish information exchanges such as questions, suggestions, clarifications and concerns about your health problem. 
95.7\% of users mentioned that they feel confident with the diagnosis and treatment advice, $78.5 \%$ reported that the doctor recalled if the reason for his previous visits, this factor is important because patients feel confident and familiar with those working in the institution, 92.4\% receive friendly treatment from physicians, $85.3 \%$ receive friendly treatment from the nurses, $80.3 \%$ are satisfied with the service received; generally seems optimal, 55.6\% expressed general agreement that the service offered by the institution is good; and $9.4 \%$ inferred that the service is excellent.

Regarding respondents profile users: 72.77\% said patients and 27,245 were accompanying (Figure 1), 74.75\% were female and $25.25 \%$ were men (Figure 2), 54.81\% were relatives of the worker, the workers were $41.54 \%$ (Figure 3), 39.21\% are professionals, 38.87\% were housewives and 21.92\% other activities (Figure 4), 36.54\% is the average age of between $24-34$ years, $39.22 \%$ had bachelor's, $71.43 \%$ have an average monthly income between $\$ 2700.00$ to $\$ 6799.00$ Mexican pesos.

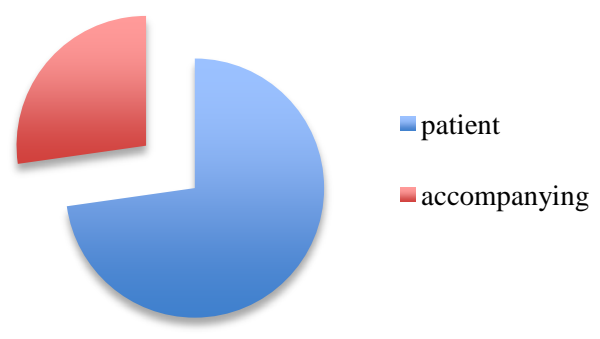

Figure 1. In profile users, $72.77 \%$ said patients and 27,245 were accompanying.

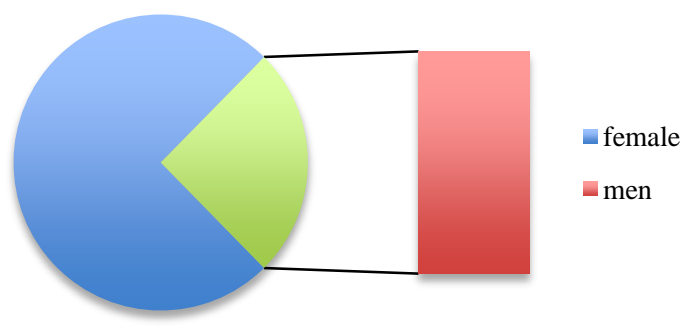

Figure 2. In profile users, $74.75 \%$ were female and $25.25 \%$ were men.

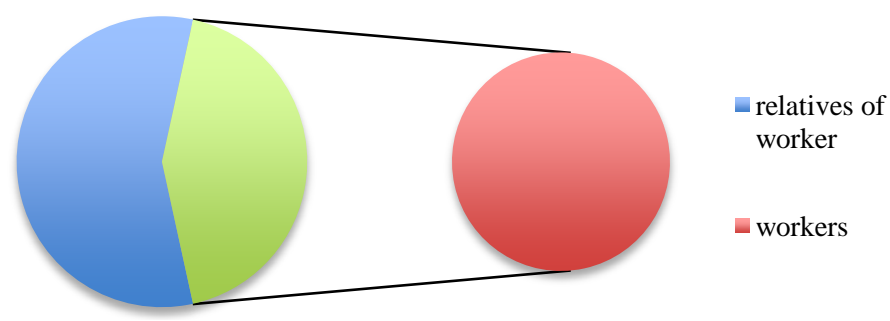

Figure 3. In profile users, the workers were $41.54 \%, 54.81 \%$ were relatives of the worker.

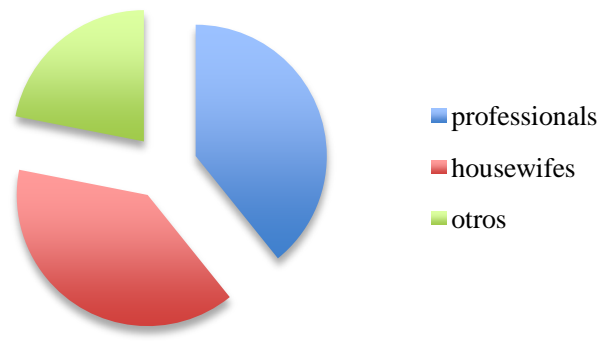

Figure 4. In profile users, $39.21 \%$ are professionals and $38.87 \%$ were housewives and $21.92 \%$ other activities. 


\section{Conclusion}

In the provision of health services, it is extremely important to identify problem areas that can negatively affect the health and care of the patient. This investigation found that, in order to provide quality service, that the organization should implement proposals for continuous improvement: generate an attitude of friendliness and helpfulness in the healthcare staff, keep detailed records of each patient and have open appointments for patients requiring emergency consultation, have the right furniture and sufficient space in the waiting room and offices, provide entertainment for those in the unit, provide leaflets, renew published information, upgrade technology equipment, receive regular training specialists, empower nurses properly, accelerate time waiting in the provision of services and make a record of the most popular drugs among others.

\section{References}

[1] Tamimi, N. (1996) How Firms Define and Measure Quality. Production and Inventory Management Journal, 37, 3439.

[2] Torres, P. and Carolina, V. (2006) Calidad total en la atención al cliente: pautas para garantizar la excelencia en el servicio. 1st Edition, Ideaspropias Editorial, España, 28.

[3] Mejía, B. (2009) Auditoría médica. 5th Edition, Ecoe Ediciones, Bogotá, 60-80.

[4] Asorey, G. (2003) La calidad del servicio y el profesional de salud. Research \& Development Center, Argentina, 130135.

[5] Santiago, M.P. (2012) Satisfacción al cliente. 1st Edition, Pearson Educación, México, 235-237.

[6] Bigné, E., Moliner, M.A. and Sánchez, J. (1997) Calidad y satisfacción en los servicios hospitalarios esenciales y periféricos: Investigación y marketing. Área de Comercialización e Investigación de Mercados. Dpto. de Admón. de Empresasy Marketing, Facultad de Ciencias Jurídicas y Económicas, Universitat Jaume 1, Castellón, 55-61.

[7] Hayes, B.E. (2009) Cómo medir la satisfacción del cliente. Ediciones Gestión, Barcelona, 2002, 59-76.

[8] Benassini, M. (2009) Introducción a la investigación de mercados: un enfoque para América Latina. 2nd Edition, Pearson Educación, México, 65.

[9] Carl Jr., M. and Gates, R. (2011) Investigación de mercados. 8th Edition, CENGAGE Learning, México, 302-329. 
Scientific Research Publishing (SCIRP) is one of the largest Open Access journal publishers. It is currently publishing more than 200 open access, online, peer-reviewed journals covering a wide range of academic disciplines. SCIRP serves the worldwide academic communities and contributes to the progress and application of science with its publication.

Other selected journals from SCIRP are listed as below. Submit your manuscript to us via either submit@scirp.org or Online Submission Portal.
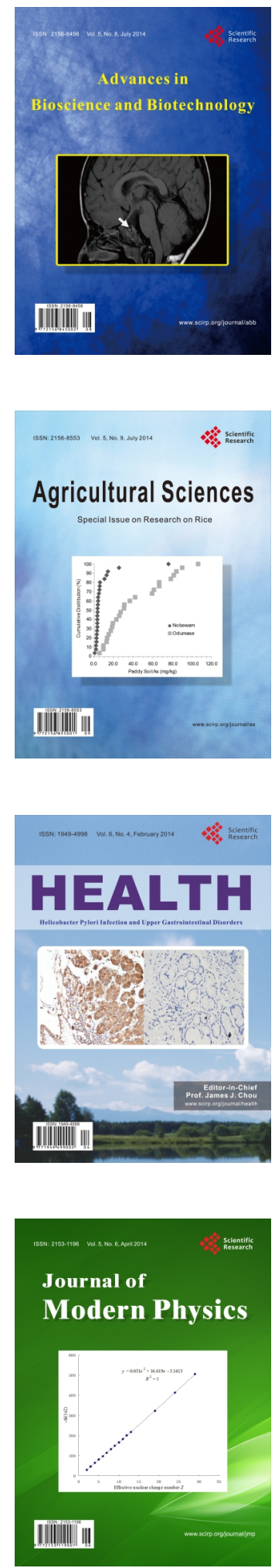
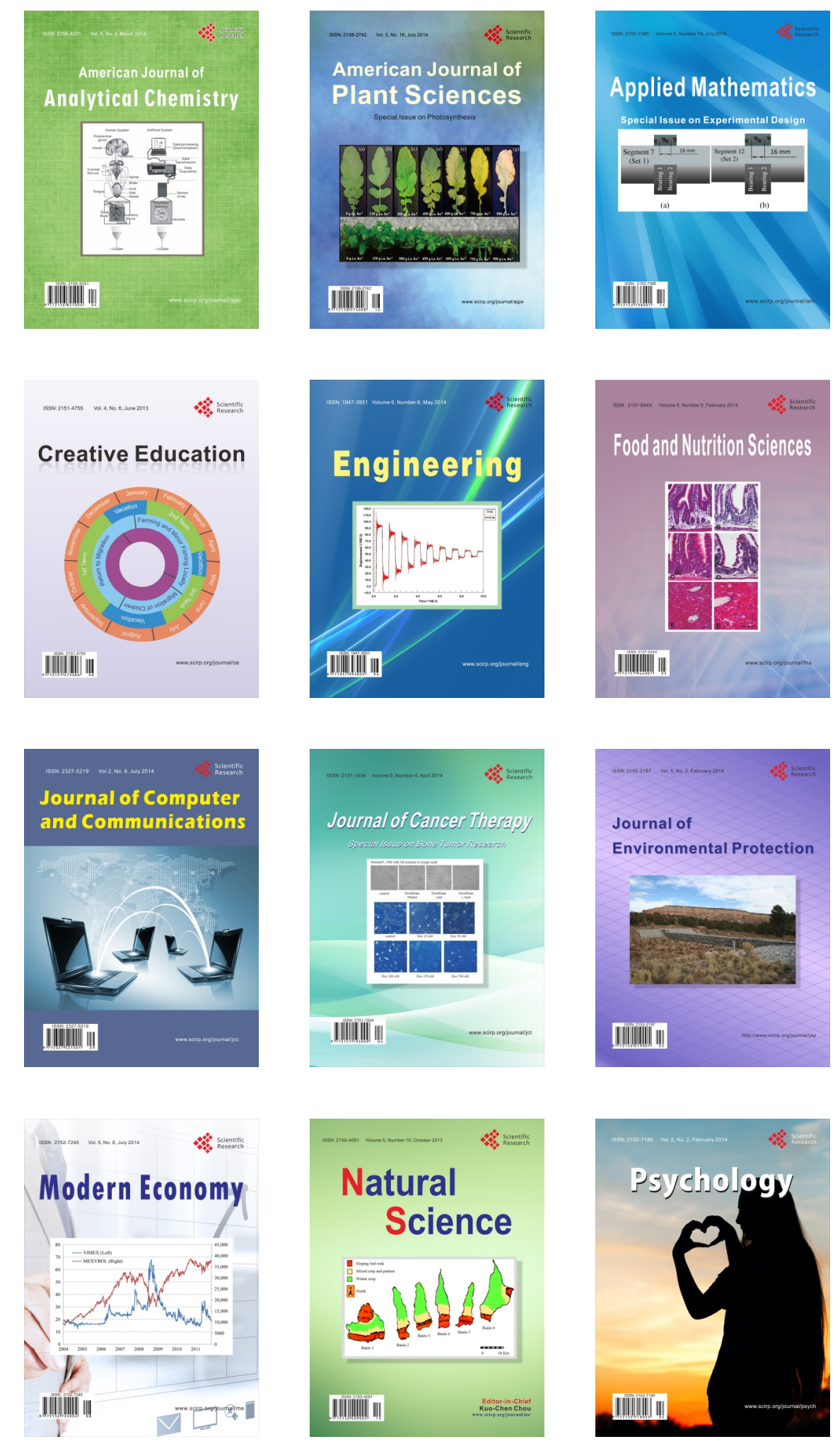